Tersedia online di: http://ejournal-balitbang.kkp.go.id/index.php/jra

\title{
PENINGKATAN KUALITAS NUTRIEN ONGGOK YANG DIFERMENTASI MENGGUNAKAN Bacillus megaterium SS4b SEBAGAI BAHAN BAKU PAKAN IKAN
}

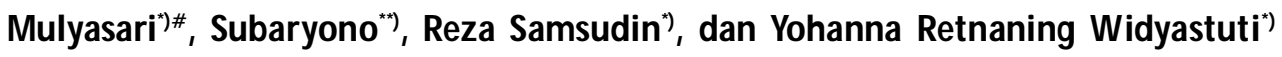 \\ * Balai Riset Perikanan Budidaya Air Tawar dan Penyuluhan Perikanan \\ Jl. Sempur No. 1, Bogor 16129 \\ *) Balai Besar Riset Pengolahan Produk dan Bioteknologi Kelautan dan Perikanan \\ Jl. KS Tubun, Petamburan VI, Slipi, Jakarta Pusat 10260
}

(Naskah diterima: 17 Januari 2018; Revisi final: 22 Juni 2018; Disetujui publikasi: 22 Juni 2018)

\begin{abstract}
ABSTRAK
Onggok adalah hasil produk samping pengolahan ubi kayu menjadi tapioka yang berpotensi dikembangkan sebagai bahan baku pakan ikan. Permasalahan yang dihadapi yaitu kecernaan onggok masih relatif rendah sehingga perlu ditingkatkan melalui teknik fermentasi. Tujuan penelitian ini adalah mengevaluasi kemampuan bakteri B. megaterium SS4b dalam menyederhanakan nutrien kompleks dari onggok, serta menentukan dosis bakteri yang sesuai untuk proses tersebut. Penelitian ini terdiri atas dua tahap yaitu: 1) penentuan aktivitas enzim selulase, amilase, dan protease bakteri B. megaterium SS4b secara semi-kualitatif; 2) penentuan dosis inokulum yang efektif untuk proses fermentasi onggok $(0 \% 3 \%, 6 \%$ dan $9 \%$. Parameter yang diukur meliputi glukosa terlarut/gula pereduksi, protein terlarut, protein kasar, serat kasar, dan kecernaan protein secara in vitro. Percobaan dilakukan menggunakan rancangan acak lengkap (RAL) dengan empat perlakuan beda dosis bakteri untuk fermentasi onggok dan tiga ulangan. Hasil penelitian menunjukkan bahwa B. megaterium SS4b memiliki aktivitas selulase, amilase, dan protease, serta mampu menghidrolisis onggok. Dosis penambahan isolat bakteri sebanyak $9 \%$ pada kepadatan $10^{11} \mathrm{sel} / \mathrm{mL}$ dan inkubasi selama 72 jam merupakan dosis terbaik dalam meningkatkan kualitas nutrien onggok. Proses fermentasi ini dapat meningkatkan kandungan protein terlarut, kecernaan protein, ketersediaan gula pereduksi, dan penurunan serat onggok berturut-turut adalah sebesar 2,9 kali, tiga kali, satu kali, dan enam kali dibandingkan dengan kontrol.
\end{abstract}

\section{KATA KUNCl: Bacillus megaterium SS4b; fermentasi; kualitas; onggok; pakan ikan}

ABSTRACT: Enhancement of nutrient quality of cassava starch residue as fish feedstuff through fermentation using Bacillus megaterium SS4b. By: Mulyasari, Subaryono, Reza Samsudin, and Yohanna Retnaning Widyastuti

Cassava starch residue is a by-product in tapioca production that has the potential to be used as one of the ingredients in fish feed. The problem was that the digestibility of cassava starch residue was relatively low but could be improved through fermentation. The purpose of this study was to evaluate the ability of $\mathbf{B}$. megaterium SS4b bacteria in simplifying the nutrient complex of cassava starch residue and determine the appropriate bacterial dose for the process. The study consisted of two stages: 1) determining, semi-qualitatively, the activity of cellulase, amylase, and protease enzyme of B. megaterium SS4; 2) determining the effective inoculum dose for the fermentation process of cassava starch residue $(0 \% 3 \% 6 \%$ and $9 \%$. Parameters measured included dissolved glucose/reducing sugar, dissolved protein, crude protein, crude fibre, and protein digestibility in vitro. The experiment was arranged in a completely randomized design (CRD) with four different treatments of bacterial dose for fermentation of cassava starch residue and three replicates. The results showed that $\mathbf{B}$. megaterium $\mathrm{SS} 4 \mathrm{~b}$ has cellulase, amylase, and protease activities and was able to hydrolyze cassava starch residue. The dosage level of the bacterial isolate at $9 \%$ with a density of 1011 cells $\mathrm{mL}-1$ and incubation for 72 hours was the best treatment in improving the nutrient quality of cassava starch residue. This fermentation process could increase soluble protein content, protein digestibility, availability of reducing sugar, and decrease significantly the fiber content of cassava starch residue

\section{KEYWORDS: Bacillus megaterium; fermentation; quality; cassava starch residue; fish feed}

\footnotetext{
\# Korespondensi: Balai Riset Perikanan Budidaya Air Tawar dan

Penyuluhan Perikanan. Jl. Sempur No. 1, Bogor 16129,

Indonesia.

Tel. + 622518313200

E-mail: mulyasari_bogor@yahoo.co.id
} 


\section{PENDAHULUAN}

Pakan merupakan salah satu faktor penting penentu keberhasilan suatu usaha budidaya ikan, karena memberikan kontribusi tertinggi terhadap biaya produksi. Biaya pakan ini dapat mencapai 40\%89\%dari total biaya produksi (Suprayudi, 2010). Oleh karena itu, harga bahan baku pakan sangat berpengaruh terhadap tingkat keuntungan yang akan diperoleh dari usaha budidaya ikan. Sampai saat ini, bahan baku pakan seperti bungkil kedelai dan tepung ikan masih diimpor dari luar negeri sehingga harga bahan baku tersebut di pasar Indonesia cukup mahal. Salah satu upaya yang dapat dilakukan untuk mengatasi permasalahan tersebut adalah dengan memanfaatkan bahan pakan lokal alternatif, yang memiliki kualitas yang cukup baik dan ketersediaannya terjamin sepanjang tahun. Hasil samping pertanian atau agroindustri merupakan sumber bahan baku pakan lokal yang ketersediaannya cukup melimpah di Indonesia, di mana hasil samping tersebut salah satunya adalah onggok (Yuwono \& Hadi, 2008).

Onggok adalah hasil produk samping pengolahan ubi kayu menjadi tapioka. Setiap ton ubi kayu bisa menghasilkan $114 \mathrm{~kg}$ onggok (Tarmudji, 2004) atau sekitar $11,4 \%$ jika setengah dari produksi ubi kayu tahun 2015 yang mencapai 21,8 juta ton (BPS, 2016) diproses menjadi tepung tapioka, maka onggok yg dihasilkan dapat mencapai 1,24 juta ton. Jumlah tersebut sangat besar untuk dimanfaatkan sebagai bahan baku pakan ikan. Onggok mengandung energi sebesar $3.000 \mathrm{kkalkg}^{-1}$ (Kalsum \& Sjofjan, 2008) sehingga dapat dimanfaatkan sebagai salah satu sumber energi pada pakan ikan. Kelemahan onggok adalah kandungan serat kasarnya yang cukup tinggi yaitu $14,27 \%$, yang menjadi pembatas utama pemanfaatan onggok untuk bahan pakan (Wizna et al., 2009). Mengingat onggok berpotensi dimanfaatkan sebagai bahan baku pakan ikan, maka kualitas nutriennya perlu ditingkatkan, salah satunya dengan proses fermentasi.

Fermentasi adalah proses penggunaan mikroba seperti bakteri atau kapang untuk mengubah suatu substrat menjadi produk tertentu yang diinginkan. Fermentasi memiliki kapasitas untuk meningkatkan kualitas nutrien dan sifat fungsional dari suatu substrat (Frias et al., 2008); serta banyak digunakan untuk meningkatkan ketersediaan nutrien (Hotz \& Gibson, 2007). Fermentasi dapat meningkatkan kecernaan pakan dengan cara melepas ikatan senyawa kompleks menjadi senyawa yang mudah dicerna, baik itu molekul protein, lemak, maupun karbohidrat seperti pati dan serat.
Pada penelitian sebelumnya, telah diperoleh isolat bakteri Bacillus megaterium strain baru yaitu Bacillus megaterium SS4b yang memiliki kemampuan menghasilkan alginat lyase dan dapat digunakan dalam produksi oligosakarida alginat (Subaryono et al., 2015; Subaryono et al., 2016). Bakteri B. megaterium SS4b tersebut juga dilaporkan mampu menyekresikan enzim-enzim ekstraseluler seperti amilase, protease maupun selulase (Mulyasari et al., 2015). Dalam penelitian ini dicoba pemanfaatan bakteri $B$. megaterium SS4b untuk fermentasi onggok, dengan tujuan menyederhanakan kandungan nutrien kompleks seperti protein, karbohidrat, dan lemak dalam onggok menjadi senyawa yang lebih sederhana dan lebih mudah dicerna oleh ikan.

\section{BAHAN DAN METODE}

Penelitian ini terdiri atas dua tahap yaitu: 1) penentuan aktivitas enzim selulase, amilase, dan protease bakteri B. megaterium SS4b dalam substrat pati, carboxymethylcellulose (CMC), susu skim, dan onggok secara semi-kualitatif; 2) penentuan dosis inokulum yang paling efektif untuk proses fermentasi onggok.

\section{Pembuatan Inokulum}

Satu ose kultur B. megaterium SS4b diinokulasikan pada $10 \mathrm{~mL}$ media TSB kemudian diinkubasi selama 24 jam pada suhu $28^{\circ} \mathrm{C}$ dalam kondisi statis. Setelah itu, diambil $1 \mathrm{~mL}$ kultur bakteri kemudian diinokulasikan pada $9 \mathrm{~mL}$ media TSB yang mengandung CMC 1\%dan diinkubasi selama 24-48 jam pada suhu $28^{\circ} \mathrm{C}$ dalam kondisi statis. Kultur bakteri kemudian siap digunakan untuk fermentasi.

\section{Percobaan 1. Pengujian aktivitas enzim selulase, amilase, dan protease B. megaterium SS4b secara semi-kualitatif}

Media yang digunakan dalam penelitian adalah media TSA yang terdiri atas 1,5\%kasein (pankreatik); 0,5\% tepung kedelai; $0,5 \%$ sodium klorida; dan $1,5 \%$ agar (Oxoid). Untuk menguji kemampuan bakteri menghasilkan selulase, media TSA ini ditambahkan $1 \%$ CMC. Untuk menguji kemampuan bakteri menghasilkan amilase, media TSA ditambahkan $1 \%$ pati, demikian pula untuk melihat adanya aktivitas proteolitik media TSA ini ditambahkan $1 \%$ susu skim. Untuk melihat kemampuan bakteri dalam memanfaatkan onggok, media TSA ini ditambahkan $1 \%$ onggok. Penyiapan media TSA yang mengandung bahan uji tersebut yaitu sebanyak $40 \mathrm{~g}$ TSA dilarutkan dalam $1 \mathrm{~L}$ aquades dan ditambahkan $1 \mathrm{~g}$ CM C atau pati atau susu skim atau onggok sesuai jenis uji yang dilakukan. Volume media dibuat menjadi $100 \mathrm{~mL}$ 
dengan penambahan akuades, dan disterilisasi dengan autoklaf pada suhu $121^{\circ} \mathrm{C}$, tekanan 1,1 atm selama 15 menit.

Aktivitas enzim selulase, amilase, dan protease secara semi-kuantitatif dapat diketahui dengan cara mengukur zona bening pada cawan petri yang mengandung media uji. Pengujian aktivitas enzim selulase secara semi-kuantitatif dilakukan sebagai berikut. Satu ose kultur B. megaterium SS4b ditempelkan pada permukaan media TSA yang sudah ditambahkan dengan bahan uji dan diinkubasi selama $48 \mathrm{jam}$. Setelah $48 \mathrm{jam}$, kemudian dilihat pembentukan zona bening yang dihasilkan bakteri. Pada media yang mengandung $\mathrm{CMC}$, pati, dan onggok diberi larutan iodin $1 \%$ untuk melihat ada tidaknya pembentukan zona bening. Indeks selulase kemudian diukur menggunakan rumus (Febriyanto et al., 2015):

$$
I S=\left(\frac{\emptyset T Z B-\varnothing K B}{\varnothing K B}\right)
$$

$$
\begin{aligned}
& \text { di mana: IS = indeks selulase } \\
& \varnothing \text { TZB = diameter total zona bening }(\mathrm{cm}) \\
& \varnothing \mathrm{KB}=\text { diameter koloni bakteri }(\mathrm{cm})
\end{aligned}
$$

Penghitungan indeks amilase dan protease dihitung menggunakan rumus yang sama dengan indeks selulase.

\section{Percobaan 2. Penentuan dosis inokulum untuk proses fermentasi onggok}

Sebanyak $25 \mathrm{~g}$ onggok ditambah dengan akuades steril $70 \mathrm{~mL}$ pada wadah aluminium foil steril kemudian diaduk secara merata. Selanjutnya ditambahkan isolat bakteri B. megaterium SS4b dengan kepadatan bakteri $10^{11} \mathrm{cfu} \mathrm{mL}^{-1}$ dan dosis 0\% 3\% 6\% dan 9\%(v/v) dari volume media yang digunakan, ditutup menggunakan plastic wrap. Proses inokulasi ini dilakukan secara aseptis. Onggok kemudian difermentasi dalam kondisi statis pada suhu $37^{\circ} \mathrm{C}$ selama dua hari. Setelah proses fermentasi selesai, onggok dikeringkan dengan oven pada suhu $60^{\circ} \mathrm{C}$ selama $2-3$ hari.

\section{Komposisi Kimia Onggok}

Analisis kandungan glukosa terlarut/gula pereduksi onggok mengacu pada Miller (1959) dengan sedikit modifikasi. Onggok hasil fermentasi sebanyak $1 \mathrm{~g}$ diekstrak dengan $20 \mathrm{~mL}$ akuades, disaring dan dimasukkan ke dalam labu ukur $100 \mathrm{~mL}$, ditera sampai tanda batas. Setelah itu, diambil $1 \mathrm{~mL}$ dan diencerkan kembali sampai $100 \mathrm{~mL}$. Sebanyak $1 \mathrm{~mL}$ sampel dalam $0,05 \mathrm{M}$ buffer asetat ( $\mathrm{pH} \mathrm{4,8)} \mathrm{ditambahkan} 3 \mathrm{~mL}$ reagen DNS dan dididihkan selama lima menit. Setelah dingin, absorbansi diukur dengan spetrofotometer Eppendorf pada panjang gelombang $550 \mathrm{~nm}$. Sebagai standar digunakan glukosa 0,6-4 $\mu \mathrm{molmL}^{-1}$ dalam 0,05 M buffer asetat (pH 4.8). Analisis kadar protein terlarut onggok hasil fermentasi dilakukan menggunakan metode Bradford (Mulyasari, 2017). Sampel onggok hasil fermentasi dosis $0 \% 3 \% 6 \%$ dan $9 \%$ masing-masing sebanyak $0,5 \mathrm{~g}$ ditambah $5 \mathrm{~mL}$ Tris $\mathrm{HCl} \mathrm{pH}$ 6,5 kemudian disentrifuse dengan kecepatan $10.000 \mathrm{rpm}$ selama 20 menit. Sampel diambil 0,5 $\mathrm{mL}$ dan ditambahkan 0,5 mL larutan Bradford kemudian diinkubasi pada suhu kamar selama 15 menit. Absorbansi diukur pada panjang gelombang $595 \mathrm{~nm}$. Sebagai standar digunakan bovine serum albumin (BSA) (100 mg dalam $100 \mathrm{~mL}$ akuades). Kandungan protein kasar onggok yang difermentasi (dosis $0 \%$ $3 \%$ 6\% dan 9\% dilakukan dengan metode Kjeldahl. Kandungan serat kasar onggok difermentasi (dosis $0 \% 3 \% 6 \%$ dan $9 \%$ dengan meto de gravimetri setelah dilakukan pemanasan pencucian contoh dalam asam dan basa secara bergantian. Kadar abu ditentukan dengan pembakaran contoh dalam tanur pada suhu $550^{\circ} \mathrm{C}$.

Penentuan kecernaan protein dilakukan secara in vitro (Ali et al., 2009). Analisis dilakukan menggunakan enzim yang diekstrak dari saluran pencernaan ikan nila (25 ekor) berukuran rata-rata $10 \pm 68 \mathrm{~g}$ dengan berat total saluran pencernaan $10,8 \mathrm{~g}$. Enzim saluran pencernaan ikan nila diekstrak dengan cara menambahkan larutan akuades dingin dengan perbandingan 1:10, dan digerus menggunakan mortar sampai halus. Sampel kemudian disentrifugasi menggunakan alat centrifuge Hanil Mega 17R pada kecepatan $12.000 \mathrm{rpm}$ selama 15 menit pada suhu $4^{\circ} \mathrm{C}$, dan filtratnya diambil sebagai ekstrak enzim saluran pencernaan ikan nila. Pengukuran kecernaan protein dilakukan menggunakan metode pH drop (Ali et al., 2009). Onggok hasil fermentasi dengan dosis $0 \% 3 \%$ $6 \%$ dan $9 \%$ masing-masing ditimbang dengan berat yang ekuivalen dengan $160 \mathrm{mg}$ protein kasar (hasil analisis proksimat) dan dicampur dengan $20 \mathrm{~mL}$ akuades dan $2 \mathrm{~mL}$ ekstrak enzim pencernaan. Campuran disesuaikan pH-nya menjadi delapan menggunakan $\mathrm{NaOH}$ dan $\mathrm{HCl}$. Selanjutnya campuran diinkubasikan selama 10 menit. Penurunan pH selama inkubasi diukur dengan pH meter Hanna Instrument setiap menit.Sebagai standar proteindigunakan kasein sebanyak $170 \mathrm{mg}$ dan diperlakukan sama seperti pada perlakuan onggok. Kecernaan protein dikalkulasikan sebagai berikut:

$$
\begin{aligned}
& \text { Kecernaan protein }=\frac{-\Delta \mathrm{pH} \text { sampel }}{-\Delta \mathrm{pH} \text { kasein }} \times 100 \\
& -\Delta=\text { perbedaan } \mathrm{pH} \text { selama } 10 \text { menit }
\end{aligned}
$$


Percobaan perlakuan dosis bakteri dilakukan menggunakan rancangan acak lengkap (RAL) dengan empat perlakuan dan tiga ulangan. Data parameter kecernaan protein kemudian ditabulasi menggunakan bantuan excel 2013 dan dianalisis statistik menggunakan ANOVA (Analysis of Variance) dengan software SPSS versi 20.0 .

\section{HASIL DAN BAHASAN}

Berdasarkan hasil uji aktivitas enzim selulase, amilase, dan protease, serta kemampuan mendegradasi onggok terlihat bahwa bakteri $B$. megaterium SS4b yang diisolasi dari rumput laut Sargassum sp. positif memiliki aktivitas ketiga enzim tersebut. Aktivitas enzim ini terlihat dari munculnya zona bening di sekitar koloni bakteri setelah ditambahkan larutan iodin (Gambar 1). Dari zona bening yang terbentuk, diperoleh nilai indeks selulolitik yang terukur masing-masing sebesar selulolitik 1,15 $\pm 0,077$; amilolitik 0,20 $\pm 0,071$; dan proteolitik $0,29 \pm 0,152$; serta mampu mendegradasi onggok dengan indeks zona hidrolisis sebesar 0,27 \pm 0,008 seperti ditampilkan pada Tabel 1 .

Zona bening yang terbentuk pada media agar yang masing-masing mengandung pati, CMC atau susu skim mengindikasikan bahwa B. megaterium SS4b memiliki aktivitas enzim amilase, selulase, dan protease. $\mathrm{Hal}$ ini sesuai dengan sejumlah literatur yang melaporkan bahwa B. megaterium memiliki aktivitas amilase (Oyeleke et al., 2010; Gurudeeban et al., 2011); aktivitas selulase (Shobharani et al., 2013; Shakoor et al., 2013); dan aktivitas protease (Rajkumar et al., 2011; Asker et al., 2013). Bakteri B. megaterium SS4b dapat pula menghidrolisis onggok yang terlihat dari zona bening yang terbentuk pada media agar yang mengandung onggok. Karbohidrat onggok yang terdiri atas pati dan serat kasar merupakan sumber nutrien bagi $B$. megaterium SS4b. Bakteri tersebut akan menyekresikan enzim amilase dan selulase untuk dapat menghidrolisis onggok menjadi gula sederhana dan memanfaatkannya sebagai sumber energi. Amilase merupakan enzim yang mampu memutus ikatan glikosidik pada rantai polimer pati dengan menyisipkan molekul air. Hasil pemutusan tersebut akan menghasilkan gugus aldehid yang dikenal sebagai gugus reduksi ujung (Nangin \& Sutrisno, 2015). Banyaknya gugus reduksi ujung berbanding lurus dengan derajat hidrolisis pati (Hii et al., 2012 dalam Nangin \& Sutrisno, 2015).

Selain amilase, bakteri B. megaterium SS4b juga memiliki aktivitas selulase yang mampu mengubah

Tabel 1. Indeks selulolitik, amilolitik, proteolitik, dan kemampuan menghidrolisis onggok dari B. megaterium SS4b

Table 1. Cellulolytic, amylolytic, proteolytic index, and the ability to hydrolysis cassava starch residue by B. megaterium SS4b

\begin{tabular}{cccc}
\hline & \multicolumn{3}{c}{ Nilai indeks enzim (Index value of enzymes) } \\
\hline $\begin{array}{l}\text { Selulase } \\
\text { Cellulase }\end{array}$ & $\begin{array}{l}\text { Amilase } \\
\text { Amylase }\end{array}$ & Protease & $\begin{array}{c}\text { Onggok (Selulase; amilase; protease) } \\
\text { Cassava starch residue (Cellulase; } \\
\text { am ylase; protease) }\end{array}$ \\
\hline $1.15 \pm 0.077$ & $0.20 \pm 0.071$ & $0.29 \pm 0.152$ & $0.27 \pm 0.008$ \\
\hline
\end{tabular}

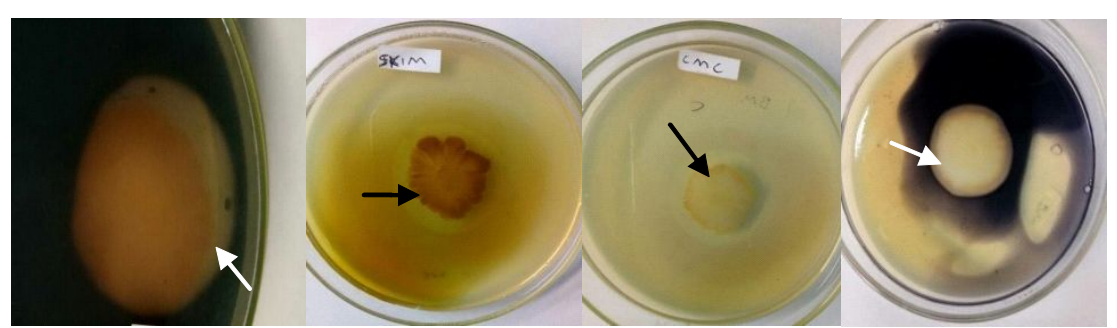

Gambar 1. Zona bening yang terbentuk dari proses hidrolisis CMC (1), pati (2), susu skim (3), dan onggok (4) oleh B. megaterium SS4b.

Figure 1. Halo formed by hydrolysis of CMC (1), starch (2), skim milk (3), and cassava starch residue by B. megaterium SS4b. 
serat kasar onggok menjadi gula sederhana. Menurut Oso et al. (2010), onggok mengandung serat kasar dalam bentuk selulosa sebesar $11,4 \%$ dan hemiselulosa $10 \%$ Bakteri B. megaterium SS4b mampu menghidrolisis selulosa onggok menggunakan enzim selulasenya. Ada tiga enzim utama yang membentuk kompleks enzim selulase untuk mendegradasi selulosa, yaitu endo-â-selulase/glukanase yang bekerja dengan cara memotong rantai molekul yang memiliki tingkat kristalinitas rendah dalam serat selulosa sehingga menciptakan ujung rantai bebas, ekso-âselulase/glukanase yang bekerja dengan cara memotong molekul lebih lanjut dengan melepaskan unit selobiose dari ujung rantai bebas, dan â-glukosidase yang bekerja dengan cara menghidrolisis selobiosa menjadi glukosa (Mussato \& Teixeira, 2010).

Proses hidrolisis onggok menjadi senyawa yang lebih sederhana dipengaruhi oleh dosis inokulum bakteri. Hal ini terlihat dari hasil pengukuran glukosa terlarut, kadar serat, protein terlarut, dan protein kasar pada penelitian ini yang menunjukkan adanya hubungan dengan dosis inokulum yang ditambahkan. Pengaruh dosis inokulum B. megaterium SS4b terhadap nilai glukosa terlarut disajikan pada Gambar 2. Semua perlakuan dosis penambahan B. megaterium SS4b menghasilkan kadar glukosa terlarut yang lebih tinggi dibanding kontrol (dosis $0 \%$. Semakin tinggi dosis inokulum yang ditambahkan, kadar glukosa terlarut yang dihasilkan cenderung semakin tinggi. Kandungan glukosa terlarut tertinggi terdapat pada dosis $9 \%$ $\left(17,07 \mathrm{mg} \mathrm{g}^{-1}\right)$ dan terendah terdapat pada dosis $0 \%$ $\left(14,67 \mathrm{mg} \mathrm{g}^{-1}\right)$. Glukosa terlarut pada penambahan B. megaterium SS4b dosis 3\%tidak berbeda nyata dengan dosis $6 \%(P>0,05)$ tetapi keduanya lebih rendah dan berbeda nyata dengan dosis $9 \%(P<0,05)$. Menurut Sandi et al. (2010), penambahan inokulum menyebabkan pertumbuhan bakteri pada substrat semakin banyak, sehingga aktivitas enzim dalam mengurai komponen serat menjadi molekul yang lebih sederhana juga meningkat. Semakin tinggi dosis inokulum yang ditambahkan maka jumlah bakteri starter yang tersedia untuk memulai proses fermentasi semakin banyak, sehingga fermentasi akan berlangsung lebih cepat.

Hasil analisis glukosa terlarut berbanding terbalik dengan hasil analisis serat kasar, di mana semakin tinggi dosis inokulum yang ditambahkan, kadar serat onggok semakin menurun (Gambar 3). Dosis inokulum $0 \%$ menghasilkan kadar serat kasar tertinggi yaitu $14,83 \%$ sedangkan yang terendah adalah pada dosis 9\% sebesar $9,42 \%$ Hasil uji statistik menunjukkan bahwa fermentasi menggunakan B. megaterium SS4b berpengaruh nyata terhadap kandungan kadar serat kasar onggok $(P<0,05)$. Meskipun demikian kandungan serat kasar antar perlakuan dosis 3\% $6 \%$ dan $9 \%$ tidak berbeda nyata $(P>0,05)$ tetapi lebih

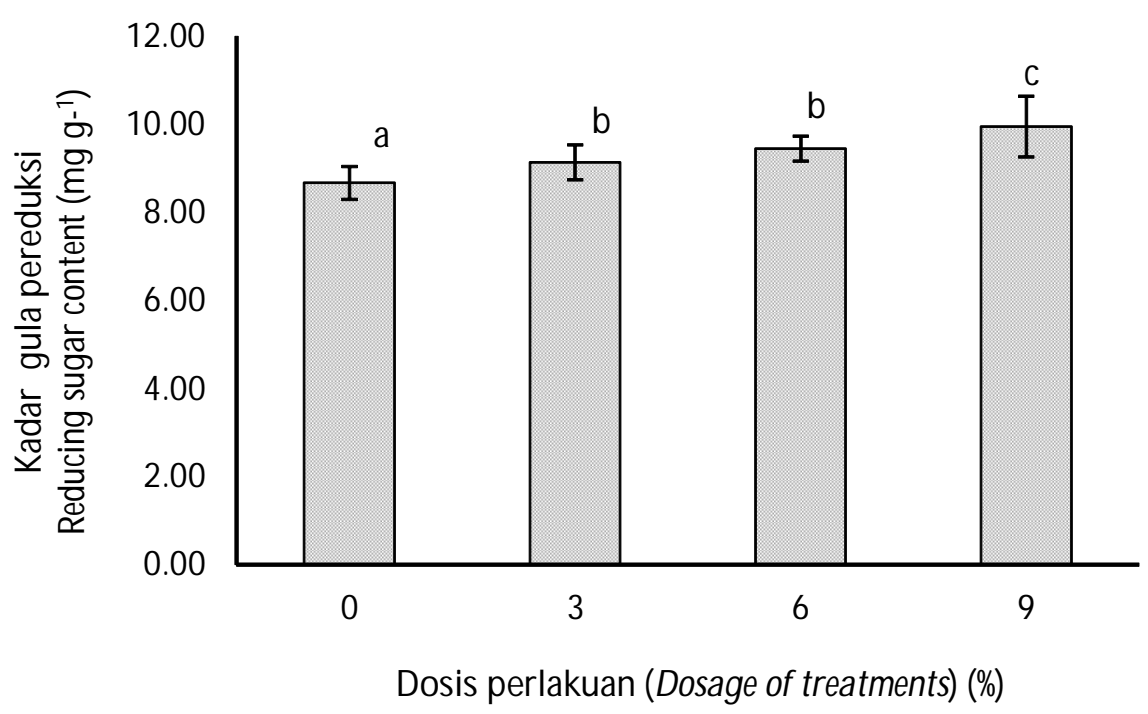

Gambar 2. Kadar gula pereduksi ( $\mathrm{mg} \mathrm{g}^{-1}$ ) onggok yang difermentasi menggunakan B. megaterium SS4b pada dosis yang berbeda (huruf yang sama mengindikasikan tidak berbeda nyata pada selang kepercayaan $95 \%$.

Figure 2. Reducing sugar content $\left(\mathrm{mg} \mathrm{g}^{-1}\right)$ of cassava starch residue fermented by B. megaterium SS4b at different doses (the same letter indicates no significant difference at $95 \%$ confidence interval). 


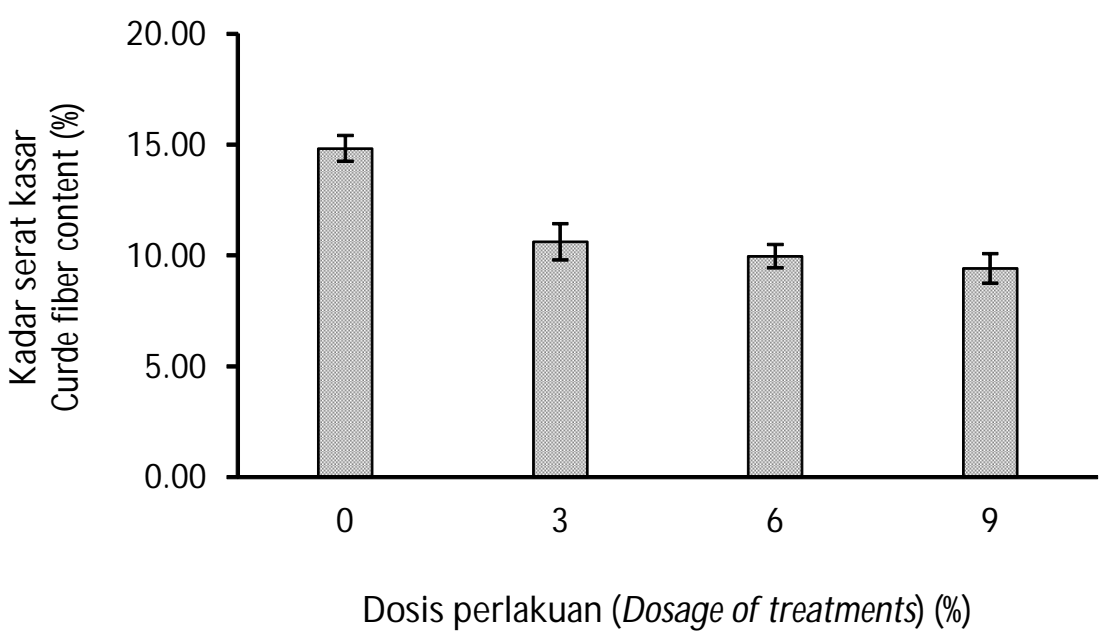

Gambar 3. Kandungan serat kasar (\%) onggok yang difermentasi menggunakan B. megaterium SS4b pada dosis inokulum yang berbeda (huruf yang sama mengindikasikan tidak berbeda nyata pada selang kepercayaan $95 \%$.

Figure 3. Crude fiber content (\%) of cassava starch residue fermented by $\mathbf{B}$. megaterium SS4b at different inoculum doses (the same letter indicates no significant difference at $95 \%$ confidence interval).

rendah dan berbeda nyata dibandingkan dengan kontrol. Hasil penelitian ini sejalan dengan penelitian Anggraeni et al. (2013) yang bertujuan meningkatkan kualitas nutrien limbah tahu menggunakan Bacillus amyloliquefaciens. Hasil penelitian tersebut menunjukkan bahwa bakteri B. amyloliquefaciens mampu menurunkan kadar serat limbah tahu. Semakin tinggi dosis bakteri, semakin tinggi pula penurunan serat kasar yang terukur.

Penambahan B. megaterium SS4b dengan dosis yang berbeda pada onggok berpengaruh terhadap proses depolimerisasi pati dan serat onggok tersebut. Amilum dan serat yang terdapat pada onggok mengalami proses hidrolisis menjadi senyawa yang lebih sederhana, salah satunya adalah glukosa. Peningkatan konsentrasi gula sederhana tersebut diikuti oleh peningkatan gula reduksi. Semakin tinggi konsentrasi bakteri yang ditambahkan pada onggok, semakin banyak enzim amilase dan selulase yang dihasilkan sehingga semakin banyak onggok yang didegradasi menjadi glukosa. Hal ini berakibat pada semakin tingginya kadar glukosa dalam substrat, yang tercermin dari semakin tingginya gula reduksi yang terukur. Menurut W izna et al. (2009), dosis inokulum yang tinggi akan mempercepat proses fermentasi, karena semakin tinggi dosis inokulum akan menghasilkan bakteri yang lebih banyak dan bakteri akan memproduksi enzim dalam jumlah besar sehingga substrat yang akan didegradasi juga menjadi lebih banyak.
Terjadinya proses degradasi onggok oleh $\mathrm{B}$. megaterium SS4b tercermin pula dari hasil pengukuran protein terlarut. Seperti halnya glukosa terlarut, kadar protein terlarut pada onggok yang dihidrolisis dengan B. megaterium SS4b juga meningkat seiring dengan meningkatnya dosis bakteri yang diberikan. Pengaruh dosis inokulum B. megaterium SS4b terhadap nilai protein terlarut disajikan pada Gambar 4. Semua perlakuan dosis (3\% 6\% dan 9\% menghasilkan kadar protein terlarut yang lebih tinggi dan berbeda nyata $(P<0,05)$ dibandingkan dengan kontrol (dosis 0\%). Dalam penelitian ini, kadar protein terlarut tertinggi terdapat pada dosis $9 \%\left(125,18 \mu \mathrm{g} \mathrm{g}^{-1}\right)$ dan terendah terdapat pada dosis $0 \%\left(50,96 \mu \mathrm{g} \mathrm{g}^{-1}\right)$. Kadar protein terlarut pada dosis 3\%tidak berbeda nyata dengan dosis $6 \%$ $(P>0,05)$ tetapi kadar protein pada kedua dosis tersebut lebih rendah dan berbeda nyata dibandingkan dengan dosis $9 \%(P<0,05)$.

Peningkatan protein terlarut pada penelitian ini terjadi karena protein onggok dihidrolisis oleh enzim protease yang diseksresikan oleh B. megaterium SS4b. Semakin tinggi dosis bakteri, semakin tinggi pula protein terlarut yang terbentuk. Enzim protease mengubah protein onggok menjadi peptida atau asam amino bebas yang mudah larut. Bakteri umumnya mampu menyekresikan beberapa jenis enzim sekaligus untuk menghidrolisis substrat. Hal ini ditujukan untuk meningkatkan efektivitas pemanfaatan substrat sebagai sumber $\mathrm{N}$ bagi bakteri untuk mendukung pertumbuhannya (Mulyasari, 2017). 


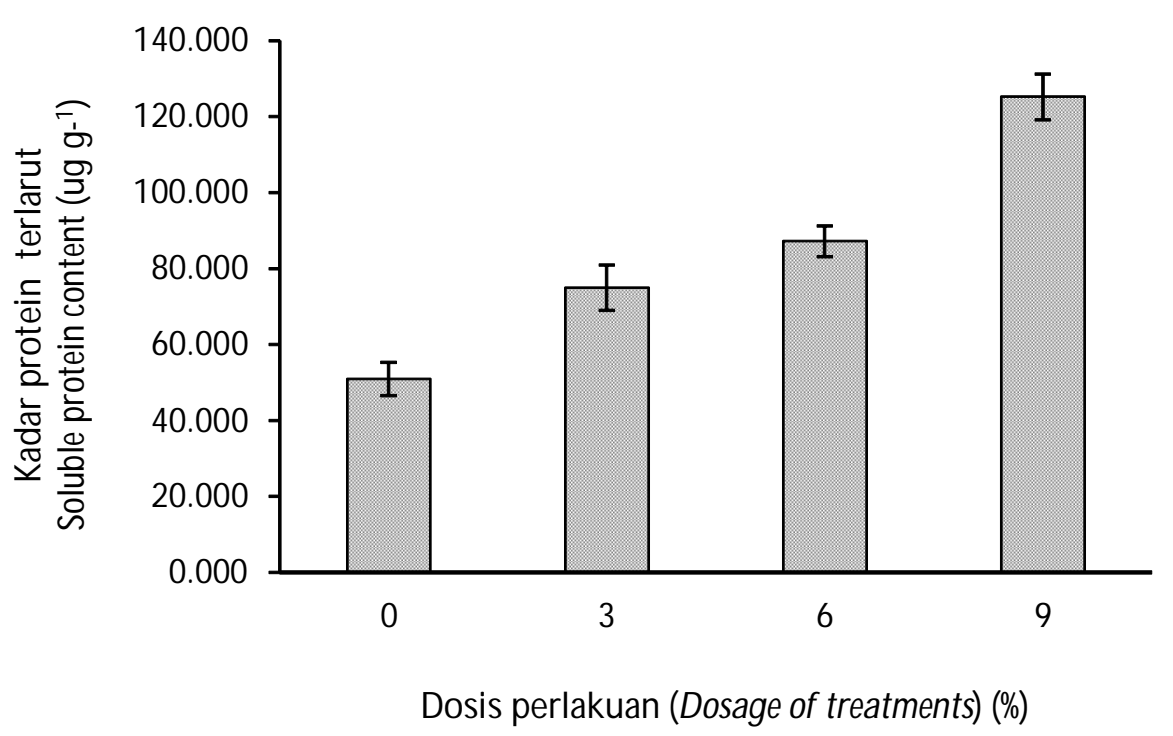

Gambar 4. Kandungan protein terlarut $\left(\mu \mathrm{g} \mathrm{g}^{-1}\right)$ onggok yang difermentasi menggunakan B. megaterium SS4b pada dosis yang berbeda (huruf yang sama mengindikasikan tidak berbeda nyata pada selang kepercayaan $95 \%$.

Figure 4. Soluble protein content $\left(\mu \mathrm{g} \mathrm{g} \mathrm{g}^{-1}\right)$ of cassava starch residue fermented by B. megaterium SS4b at different doses (the same letter indicates no significant difference at 95\%confidence interval).

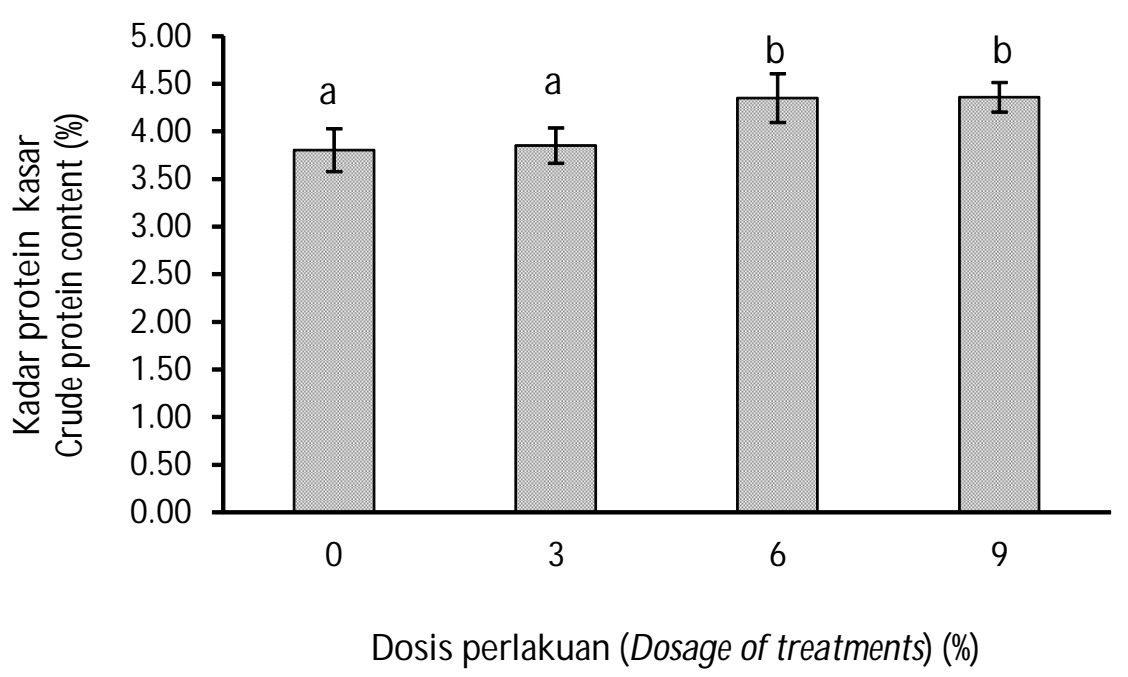

Gambar 5. Kandungan protein kasar (\% onggok yang difermentasi menggunakan B. megaterium SS4b pada dosis yang berbeda (huruf yang sama mengindikasikan tidak berbeda nyata pada selang kepercayaan $95 \%$.

Figure 5. Crude protein content (\%) of cassava starch residue fermented by B. megaterium SS4b at different doses (the same letter indicates no significant difference at 95\% confidence interval).

Peningkatan protein terlarut ini sejalan dengan hasil analisis protein kasar, di mana semakin tinggi dosis inokulum yang ditambahkan semakin tinggi pula kadar protein kasar onggok yang difermentasi menggunakan B. megaterium SS4b. Perlakuan dosis inokulum berpengaruh nyata $(P<0,05)$ terhadap kadar protein kasar onggok (Gambar 5). Semakin tinggi dosis inokulum yang ditambahkan, semakin tinggi kadar protein kasar yang terukur. Kadar protein kasar dosis $0 \%$ secara signifikan berbeda dengan $6 \%$ dan $9 \%$ $(P<0,05)$; tetapi tidak berbeda nyata dengan $3 \%$ $(P>0,05)$. Nilai tertinggi dihasilkan pada perlakuan 
dosis $9 \%$ yaitu $4,36 \%$ dan terendah adalah dosis $0 \%$ yaitu $380 \%$

Kadar protein kasar dalam penelitian ini sejalan dengan penelitian Kurniati et al. (2016). Peneliti tersebut melaporkan bahwa dosis inokulum berpengaruh terhadap kadar protein kasar fermentasi Jatropha curcas L. menggunakan Aspergillus niger dan Rhizopus oryzae. Semakin tinggi dosis inokulum yang ditambahkan, semakin tinggi kandungan protein kasar yang terukur. Hal yang sama dilaporkan pula oleh Lie et al. (2015) bahwa kadar protein kasar pada limbah solid kelapa sawit yang difermentasi menggunakan Trichoderma reesei mengalami peningkatan seiring dengan peningkatan dosis inokulum. Penulis tersebut melaporkan bahwa peningkatan protein kasar terjadi karena kapang $\mathrm{T}$. reesei mampu mengikat nitrogen dari udara. Semakin tinggi dosis inokulum bakteri yang ditambahkan, semakin banyak T. reesei yang tumbuh sehingga semakin banyak nitrogen yang bisa diikat dari udara. Bakteri B. megaterium SS4b yang digunakan dalam penelitian ini tidak termasuk ke dalam jenis bakteri penambat nitrogen dari udara. Oleh karena itu, terjadinya peningkatan kadar protein kasar dalam penelitian ini diduga terjadi karena kadar nutrien lain seperti karbohidrat (pati dan serat), mengalami penurunan selama proses fermentasi berlangsung, sehingga secara proporsional kadar protein meningkat. Hal ini kemungkinan besar terjadi karena karbohidrat lebih banyak dimanfaatkan bakteri sebagai sumber energi karena ketersediaannya yang dominan di dalam bahan. Bakteri membutuhkan energi untuk pertumbuhan dan perkembangbiakannya. Energi tersebut diperoleh dengan cara mendegradasi nutrien yang mengandung senyawa karbon seperti pati, serat, lemak, maupun protein.
Kecernaan protein onggok secara in vitro menunjukkan bahwa secara umum perlakuan fermentasi mampu meningkatkan kecernaan protein dari onggok (Tabel 2). Semakin tinggi dosis bakteri yang diberikan semakin tinggi pula kecernaan protein yang terukur. Hasil ini sejalan dengan penelitian Oboh \& Akindahunsi (2003) dalam Aro (2008) bahwa fermentasi menggunakan campuran Aspergillus niger dengan dua spesies Lactobacillus sp. mampu meningkatkan kecernaan protein secara in vitro pada bahan baku kulit ubikayu dari $66,0 \pm 3,1 \%$ menjadi $75,1 \pm 2,1 \% \mathrm{Hal}$ yang sama dilaporkan pula oleh Ogodo et al. (2018), bahwa fermentasi tepung kacang tanah bambara menggunakan bakteri asam laktat secara signifikan mampu meningkatkan kecernaan protein in vitro bahan tersebut dari $68,70 \pm 1,73 \%$ menjadi $85,24 \pm 1,21 \%$ Sedangkan Samadi et al. (2015) melaporkan bahwa fermentasi menggunakan kultur bakteri asam laktat komersial SBP mampu meningkatkan kecernaan bahan kering dan bahan organik secara in vitro pada ampas sagu masing-masing dari $68,98 \%$ menjadi $70,89 \%$ dan dari $70,41 \%$ menjadi $72,71 \%$

Berdasarkan hasil penelitian ini terlihat bahwa fermentasi onggok menggunakan bakteri $B$. megaterium SS4b mampu mengubah senyawakompleks menjadi sederhana, yang tercermin dari peningkatan gula sederhana dari $14,36 \mathrm{mg} \mathrm{g}^{-1}$ menjadi $17,07 \mathrm{mg} \mathrm{g}^{-}$ ${ }^{1}$; protein terlarut dari $50,96 \mu \mathrm{g} \mathrm{g}^{-1}$ menjadi $125,18 \mu \mathrm{g}$ $\mathrm{g}^{-1}$ dan penurunan serat dari $14,83 \%$ menjadi $9,42 \%$ sehingga mampu meningkatkan kecernaan bahan onggok dari 43,48\%menjadi 78,79\% Menurut Hasan et al. (2014), mikroba memiliki kemampuan untuk mengkatabolisme senyawa kompleks dan berperan dalam pelepasan nutrien yang terikat pada struktur

Tabel 2. Kecernaan protein secara in vitro bahan onggok yang difermentasi menggunakan B. megaterium SS4b

Table 2. In vitro protein digestibility of cassava starch residue fermented by B. megaterium SS4b

\begin{tabular}{cc}
\hline $\begin{array}{c}\text { Dosis perlakuan } \\
\text { Dosage of treatments }(\%)\end{array}$ & $\begin{array}{c}\text { Kecernaan protein in vitro } \\
\text { In vitro protein digestibility (\%) }\end{array}$ \\
\hline 0 & $36.36 \pm 15.75^{\mathrm{a}}$ \\
3 & $45.45 \pm 27.27^{\mathrm{ab}}$ \\
6 & $72.73 \pm 15.75^{\mathrm{ab}}$ \\
9 & $78.79 \pm 20.99^{\mathrm{b}}$ \\
\hline
\end{tabular}

Keterangan: Nilai padakolom yang diikuti huruf yang sama mengindikasikan tidak berbeda nyata pada selang kepercayaan $95 \%$

Remarks: Values in the same column followed by the same letter indicates no significant difference at $95 \%$ confidence interval 
sel bahan nabati yang tidak tercerna. Bakteri dapat memecah dinding sel tersebut dan mendegradasi, selulosa, hemiselulosa, dan polimer lainnya kemudian mengubahnya menjadi gula sederhana atau turunan gula. Selain itu, bakteri juga mampu menyintesis vitamin, asam organik, dan faktor pertumbuhan lainnya. Asam organik yang dihasilkan dari proses fermentasi dapat meningkatkan aktivitas enzim mikroba (suhu sekitar $22^{\circ} \mathrm{C}-25^{\circ} \mathrm{C}$ ) seperti amilase, protease, fitase, dan lipase. Enzim-enzim tersebut mampu menghidrolisis polisakarida, protein, lemak, dan fitat sehingga meningkatkan ketersediaan gula, protein, lemak sederhana, serta mineral dalam produk. Ketersediaan senyawa sederhana dalam onggok akan mempermudah proses pencernaan dan penyerapan bahan tersebut dalam saluran pencernaan ikan. Penyerapan nutrien yang lebih baik akan menghasilkan retensi protein yang lebih tinggi pada ikan. Selain itu, gula sederhana yang dihasilkan dari proses degradasi selulosa onggok dapat dimanfaatkan ikan sebagai sumber energi, sehingga protein yang tersedia disimpan untuk pembentukan jaringan tubuh atau pertumbuhan (Orire \& Sadiku, 2011). Retensi protein yang tinggi pada akhirnya akan memberikan dampak positif pada peningkatan laju pertumbuhan harian dan efisiensi pakan ikan.

Beberapa literatur melaporkan bahwa fermentasi mampu meningkatkan kualitas nutrien dari suatu bahan baku pakan ikan sehingga penggunaannya dalam pakan dapat ditingkatkan, serta dapat dimanfaatkan untuk meningkatkan pertumbuhan ikan. Handajani (2011) melaporkan bahwa penggunaan bungkil kedelai dan tepung azolla terfermentasi berpengaruh signifikan pada tingkat pertumbuhan dan parameter daya cerna ikan nila GIFT. Hal yang sama dilaporkan Dhamayanti et al. (2016) bahwa substitusi tepung ikan dengan tepung Hydrilla verticillata terfermentasi sebesar 10\% mampu meningkatkan produktivitas ikan nila. Kecernaan $\mathrm{H}$. verticillata meningkat sebesar $7 \%$ laju pertumbuhan spesifik ikan nila meningkat sebesar $24,8 \%$ dan konversi pakan sebesar $21,85 \%$ Mulyasari (2017) juga melaporkan bahwa fermentasi daun singkong menggunakan bakteri B. clausii UG3 mampu meningkatkan kecernaan daun singkong sebesar 7\% laju pertumbuhan harian ikan nila sebesar $19,80 \%$ dan efisiensi pakan sebesar 15,7\% Sedangkan Soltan \& Samra (2010) melaporkan bahwa substitusi tepung ikan dengan silase ikan sampai 25\%dalam pakan masih dapat digunakan dan tidak memberikan pengaruh negatif terhadap pertumbuhan ikan nila (Oreochromis niloticus). Penggunaan silase ini dapat mereduksi biaya pakan sebesar 7,93\%

\section{KESIMPULAN}

Bakteri B. megaterium SS4b memiliki aktivitas selulase, amilase, dan protease, serta mampu menghidrolisis onggok. Dosis inokulum $9 \%$ merupakan dosis terbaik dalam meningkatkan kualitas nutrien onggok, menghasilkan peningkatan kadar gula sederhana dari $14,36 \mathrm{mg} \mathrm{g}^{-1}$ menjadi $17,07 \mathrm{mg} \mathrm{g}^{-1}$; protein terlarut dari $50,96 \mu \mathrm{g} \mathrm{g}^{-1}$ menjadi $125,18 \mu \mathrm{g}$ $\mathrm{g}^{-1}$; dan penurunan serat dari $14,83 \%$ menjadi $9,42 \%$ serta kecernaan protein in vitro dari $36,6 \%$ menjadi $78,79 \%$

\section{UCAPAN TERIMA KASIH}

Ucapan terima kasih disampaikan kepada Balai Riset Perikanan Budidaya Air Tawar dan Penyuluhan Perikanan Bogor yang telah memfasilitasi penelitian ini. Terima kasih juga penulis ucapkan kepada Bapak Mikdarullah dan Bapak Khazaidan yang telah membantu penulis dalam melaksanakan penelitian ini.

\section{DAFTAR ACUAN}

Ali, H., Haque, M.M., Chowdury, M.M.R., \& Shariful, I. (2009). In vitro digestibility of different feed ingredients in Thai koi (Anabas testudineus). Journal of Bangladesh Agricultural University, 7(1), 205210.

Anggraeni, Hasibuan, S., Malik, B., \& Wijaya, R. (2013). Improving the quality of tofu waste as a source of feed through fermentation using the Bacillus amyloliquefaciens culture. International Journal of Advanced Science Engineering Information Technology, $3(4), 22-25$.

Aro, S.0. (2008). Improvement in the nutritive quality of cassava and its by-products through microbial fermentation. African Journal of Biotechnology, 7(25), 4789-4797.

Asker, M.M.S., Mahmoud, M.G., El-Shebwy, K., \& ElAzis, M.S.A. (2013). Purification and characterization of two thermostable protease fractions from Bacillus megaterium. Journal Genetic Engineering and Biotechnology, 11(2), 103-109.

Badan Pusat Statistik [BPS]. (2016). Produksi ubi kayu menurut Provinsi (ton) Tahun 1993-2015. Jakarta (ID): BPS.

Dhamayanti, R.R., Nursyam, H., \& Hariati, A.M. (2016). Utilization of Hydrilla verticillata fermented meal as alternative sources of protein in feed formulation for tilapia (Oreochromis sp.) growth. International Journal of Scientific \& Technology Research, 5(3), 34-35. 
Febriyanto, A., Rusmana, I., \& Raffiudin R. (2015). Characterization and identification of cellulolytic bacteria from gut of worker Macrotermes gilvus. HAYATI Journal of Biosciences, 22, 197-200.

Frias, J., Song, Y.S., Martínez-Villaluenga, C., González de Mejia, E., \& Vidal-Valverde, C. (2008). Immunoreactivity and amino acid content of fermented soybean products. Journal of Agricuture Food Chemistry, 56(1), 99-105.

Gurudeeban, S., Satyavanim K., \& Ramanathan, T. (2011). Production extracellular $\alpha$-amilase using Bacillus megaterium isolated from white mangrove (Avicenniamarina). Asian Journal of Biotechnology, p. 1-7, DOI, 10.3923/ajbkr.2011. [5 Oktober 2017].

Handajani, H. (2011). Optimalisasi substitusi tepung azolla terfermentasi pada pakan ikan untuk meningkatkan produktivitas ikan nila GIFT. Jurnal Teknik Industri, 12(2), 177-181.

Hassan, M.N., Sultan, M.Z., \& Mareum, M. (2014). Significance of fermented food in nutrition and food science. Journal of Science and Research, 6(2), 373-386.

Hotz, C. \& Gibson, R.S. (2007). Traditional food-processing and preparation practices to enhancing the bioavailability of micronutrients in plant-based diets. Journal of Nutrition, 137, 1097-1100.

Kalsum, U. \& Sjofjan, O. (2008). Pengaruh waktu inkubasi campuran ampas tahu dan onggok yang difermentasi dengan Neurosphora sitophila terhadap kandungan zat makan. Dalam Prosiding Seminar Nasional Teknologi Peternakan dan Veteriner, Bogor, Indonesia, hlm. 226-232. Pusat Penelitian dan Pengembangan Peternakan, Kementerian Pertanian.

Kurniati, T., Nurlaila, L., \& lim. (2016). Effect of inoculum dosage Aspergillus niger and Rhizopus oryzae mixture with fermentation time of oil seed cake (Jatropha curcas $L$ ) to the content of protein and crude fiber. Journal of Physics, 824(012604), 1-12. doi:10.1088/1742-6596/824/1/012064. [15 November 2017].

Lie, M., Najoan, M., \& Wolayan, F.R. (2015). Peningkatan nilai nutrien protein kasar dan serat kasar limbah solid kelapa sawit terfermentasi dengan Trichoderma reesei. Jurnal LPPM Bidang Sains dan Teknologi, 2(1), 34-43.

Miller, G.L. (1959). Use of dinitrosalicylic acid reagent for determination of reducing sugar. Analytical Chemistry, 31, 426-428.

Mulyasari, Melati, I., \& Sunarno, M.T.D. (2015). Isolasi, seleksi dan identifikasi bakteri selulolitik dari rumput laut Turbinaria sp. dan Sargassum sp. sebagai kandidat pendegradasi serat kasar pakan ikan. Jurnal Riset Akuakultur, 10(1), 51-60.

Mulyasari. (2017). Kajian pemanfaatan bakteri selulolitik untuk perbaikan kualitas bahan baku daun singkong (Manihot utilissima) dan sebagai probiotik untuk meningkatkan performa pertumbuhan ikan nila (Oreochromis niloticus). Disertasi. Sekolah Pascasarjana, Institut Pertanian Bogor.

Mussatto, S.I., \& Teixeira, J.A. (2010). Lignocellulose as raw material in fermentation processes. Current Research, Technology and Education Topics. In Mendez-Vilas (Ed). Microbiology and Microbial Technology. Extremadura (ES), p. 897-907. Formatex Publisher.

Nangin, D. \& Sutrisno, A. (2015). Enzim amilase pemecah pati mentah dari mikroba: kajian pustaka. Jurnal Pangan dan Agroindustri, 3(3), 1032-1039.

Ogodo, A.C., Ugbogu, O.C., Onyeagba, R.A., \& Okereke, H.C. (2018). Proximate composition and in-vitro starch/protein digestibility of bambara groundnut flour fermented with lactic acid bacteria (LAB)-consortium isolated from cereals. Fermentation Technology, 7(1), 1-9.

Orire, A.M. \& Sadiku, S.O.E. (2011). Protein sparing effect of carbohydrate in the practical diet of Oreochromis niloticus. Nigerian Journal of Fisheries, 8(1), 168-175.

Oso, A.O., Oso, O., Bangbose, A.M., \& Eruvbetine, D. (2010). Utilization of unpeeled cassava (Manihot esculenta) root meal in diets of weaner rabbits. Livestock Science, 127, 192-196.

Oyeleke, S.B., Auta, S.H., \& Egwim, E.C. (2010). Production and characterization of amylase produced by Bacillus megaterium isolated from a local yam peel dumpsite in Minna, Niger State. Journal of Microbiology and Antimicrobials, 2(7), 88-92.

Rajkumar, R., Jayappriyan, K.R., \& Rengasamy, R. (2011). Purification and characterization of a protease produced by Bacillus megaterium RRM2: application in detergent and dehairing industries. Journal of Basic Microbiology, 51(6), 614-624.

Samadi, Wajizah, S., \& Usman, Y. (2015). In vitro study of fermented complete feed by using sago residues as main source diet. Animal Production, 17(3), 129-137.

Sandi, S., Laconi, E.B., Sudarman, A., Wiryawan, K.G., \& Mangundjaja, D. (2010). Kualitas nutrisi silase berbahan baku singkong yang diberi enzim cairan rumen sapi dan Leuconostoc mesenteroides. Media Peternakan, 33(1), 25-30.

Shakoor, S., Aftab, S., \& Rehman, A. (2013). Characterization of cellulose degrading bacterium, Bacil- 
lus megaterium $\mathrm{S} 3$, isolated from indigenous environment. Pakistan Journal of Zoology, 45(6), 16551662.

Shobharani, P., Yogesh, D., Halami. P.M., \& Sachindra, M.N. (2013). Potential of cellulase from Bacillus megaterium for hydrolysis of Sargassum. Journal of Aquatic Food Product Technology, 22(5), 520-535.

Soltan, M.A. \& Samra, I.M. (2010). Partial or complete replacement of fish meal by fermented fish by-product silage in the diets of nile tilapia (Orechormis niloticus) fingerlings. In The Third Scientific Conference (p. 1-19). Cairo, Egypt: Al-Azhar University.

Subaryono, Ardilasari, Y., Peranginangin, R., Zakaria, F.R., \& Suhartono, M.T. (2016). Alginate lyase from Indonesian Bacillus megaterium s245 shows activity toward polymannuronate and polyguluronate. Squalen Bulletin of Marine and Fisheries Postharvest and Biotechnology, 11(2), 45-52.

Subaryono, Peranginangin, R., Suhartono, M.T., \& Zakaria, F.R. (2015). Isolasi dan identifikasi bakteri penghasil alginat lyase dari rumput laut Sargassum crassifolium. Jurnal Pasca Panen dan Bioteknologi Kelautan dan Perikanan, 10(1), 1-9.

Suprayudi, M.A. (2010). Bahan baku pangan lokal: tantangan dan harapan akuakultur Indonesia. Prosiding Simposium Nasional Bioteknologi Akuakultur III. Bogor, Indonesia: Institut Pertanian Bogor, $31 \mathrm{hlm}$.

Tarmudji. (2004). Pemanfaatan onggok untuk pakan unggas. http://www.litbang.deptan.go.id/artikel/ one/71/. [11 September 2017].

Wizna, H.A., Rizal. Y., \& Dharma, A. (2009). Improving the quality of tapioca by product (onggok) as poultry feed through fermentation by Bacillus amyloliquefaciens. Pakistan Journal of Nutrition, 8(10), 1636-1640.

Yuwono, S.D. \& Hadi, S. (2008). Production of lactic acid from onggok and tofu liquid waste with concentrate Maguro waste supplementby Streptococcus bovis. Australian Journal of Basic and Applied Sciences, 2(4), 939-942. 